\section{MEJA HIBRID BERBASIS LIMBAH SERBUK GERGAJI DAN CANGKANG TELUR UNTUK PASIEN RUMAH SAKIT}

Harini Sosiati*, Tri Wahyono, Wijaya Agus Firmansyah, Muhamad Irawansyah, Dias Saputra Utama, Yashinta Farahsani

Program Studi Teknik Mesin, Universitas Muhammadiyah Yogyakarta

\begin{abstract}
Abstrak
Limbah serbuk gergaji di berbagai daerah yang saat ini semakin bertambah, memerlukan penanganan yang efektif untuk dapat diolah menjadi produk yang bermanfaat bagi masyarakat. Melalui Program Pengembangan Desa Mitra (PPDM) yang didanai oleh Universitas Muhammadiyah Yogyakarta (UMY), limbah serbuk gergaji halus yang diperoleh pengusaha Syifa Meuble Kecamatan Mungkid, Kabupaten Magelang telah diolah menjadi meuble hibrid dalam bentuk meja makan untuk pasien di rumah sakit atau klinik. Meja dibuat dengan gerakan yang fleksibel untuk memudahkan pasien. Fabrikasi meubel (meja) hibrid dilakukan menggunakan teknologi komposit hibrid, yaitu limbah serbuk gergaji dengan fraksi berat $30 \%$ dikombinasikan dengan limbah serbuk cangkang telur ayam yang diperoleh dari pengusaha roti (10\% berat) sebagai bahan pengisi, dan epoxy resin $160 \%$ berat) sebagai bahan pengikat/matriks. Sebelum dibuat menjadi meja yang berdimensi $(64 \mathrm{~cm} \times 36$ $\mathrm{cm} \times 3 \mathrm{~cm})$, perlu dilakukan salah satu pengujian sifat mekanis terhadap bahan komposit tersebut, yaitu uji bending untuk mengetahui sifat lenturnya. Hasil uji sifat lentur menunjukkan bahwa penambahan $10 \%$ berat cangkang telur pada komposit serbuk gergaji/epoxy sedikit meningkatkan regangan lentur dan kekakuan papan komposit, masing-masing sekitar 4\%. Produk papan komposit serbuk gergaji/epoxy dan komposit hibrid serbuk gergaji/serbuk cangkang telur/epoxy menunjukkan kerapatan yang lebih tinggi dibandingkan papan partikel yang ada di pasaran. Hal ini memberikan nilai positif yang berpotensi untuk dikembangkan menjadi produk meja hibrid yang berkualitas untuk aplikasi meja pasien yang fleksibel.
\end{abstract}

Kata Kunci: Limbah Cangkang Telur; Limbah Serbuk Gergaji; Meja Hibrid; Papan Komposit

\begin{abstract}
An increase of sawdust waste in various areas needs effective handling to be processed into beneficial products to the community. Through the "Program Pengembangan Desa Mitra" (PPDM) funded by the Universitas Muhammadiyah Yogyakarta (UMY), sawdust waste fine particles obtained from furniture entrepreneur Syifa Meubel, Mungkid District, Magelang Regency has been processed into hybrid furniture in the form of dining tables for patients in hospitals or clinics. The table is made with flexible movement to make it easier for the patient. Fabrication of hybrid furniture (table) is carried out using hybrid composite technology, namely sawdust waste with a weight fraction of $30 \%$ combined with chicken eggshell waste powder obtained from the baker (10 wt.\%) as fillers and epoxy resin (60 wt.\%) as a binder/matrix. Before being made into a table with dimensions $(64 \mathrm{~cm} \times 36 \mathrm{~cm} \times 3 \mathrm{~cm})$, it is necessary to do testing for one of the mechanical properties of the composite material, namely a bending test, to determine its flexural properties. The results of the flexural properties test showed that the addition of $10 \%$ by weight of eggshell to the sawdust/epoxy composite slightly increased the flexural strain and stiffness of the composite board, each by about $4 \%$. The sawdust/epoxy composite board and sawdust/eggshell powder/epoxy hybrid composite showed a higher density than the commercial particleboard. This result provides the valuable potential for developing good quality and flexible hybrid table products applied to patients.
\end{abstract}

Keywords: Eggshells; Sawdust Waste; Hybrid Table; Composite

\author{
*Corresponding author \\ Harini Sosiati \\ Email: hsosiati@ft.umy.ac.id
}




\section{PENDAHULUAN}

Jenis kayu yang ada di Indonesia adalah Kayu Jati, Meranti, Cendana, Mahoni, Sonokeling, Merbau, Kelapa dan Ulin (Kurniawan, 2020). Dalam hal ini kayu jati adalah jenis kayu yang memiliki kepadatan paling tinggi dan memiliki sifat antibakteri sehingga tidak mudah lapuk serta tahan benturan. Pada industri kerajinan kayu, produk furniture atau meuble yang berbahan dasar kayu jati menjadi produk meuble yang paling mahal karena kualitas bahannya, tahan lama dan elegan untuk diproduksi sebagai kebutuhan dekorasi interior dan eksterior. Selain tahan lama dan sangat awet, kayu jati juga memiliki kombinasi sifat yang baik dan tidak dimiliki oleh jenis kayu lain, yaitu dapat digunakan untuk tujuan kayu pertukangan, memiliki penampakan yang cukup baik, kembang susut sedikit, dan pengerjaan yang mudah serta memiliki kemampuan menahan beban dengan baik (Pasaribu \& Sisilia, 2021). Akan tetapi, karena ketersediaan sumber kayu jati yang terbatas maka para perajin atau pengusaha meuble cenderung beralih menggunakan jenis kayu lainnya atau bahan alternatif lain yang lebih murah.

Selain itu, pada umumnya para perajin kayu dan pengusaha meuble selalu menghasilkan limbah serbuk gergaji dan potongan-potongan kayu yang mencapai $50 \%$ dari total volume yang diproduksi menjadi meuble. Hingga saat ini pembuangan limbah serbuk gergaji tersebut masih menjadi masalah yang belum terpecahkan karena belum dapat dimanfaatkan secara optimal. Oleh karena itu perlu mendapat perhatian untuk diberikan solusinya, yaitu mengolah limbah tersebut menjadi produk yang unggul dan inovatif.

Sebenarnya hasil olahan dengan memanfaatkan limbah serbuk gergaji telah ada dipasaran diantaranya adalah produk kerajinan contohnya tempat sampah dan bingkai lukisan, sebagai bahan bakar dalam bentuk briket (Suwaedi, 2018), dan dibuat papan partikel (Cahyandari, 2007; Supriyanto et al., 2020). Dari beberapa hasil olahan tersebut, papan partikel (Gambar 1) yang dapat diproduksi menjadi meuble masih menunjukkan kerapatan yang rendah (lihat anak panah). Oleh karena itu, dari sisi kekuatan, waktu pakai dan kerentanan terhadap air, produk meuble dari papan partikel belum dapat direkomendasikan menjadi produk yang unggul.

Di Kabupaten Magelang banyak pengusaha meuble, tentunya menghasilkan banyak limbah gergaji. Salah satu pengusaha "Syifa Meuble" di Dusun Pabelan 1, Kelurahan Pabelan, Kecamatan Mungkid, Kabupaten Magelang menghasilkan tiga macam serbuk gergaji dengan ukuran yang berbeda, yaitu halus, sedang dan kasar. Untuk limbah serbuk gergaji yang kasar, setiap minggunya telah disalurkan ke pelanggan yang dimanfaatkan oleh pabrik tahu sebagai bahan bakar. Namun, untuk penanganan limbah serbuk gergaji yang halus belum mendapatkan solusi dengan baik. Selama ini, limbah tersebut hanya ditimbun dan dibakar.

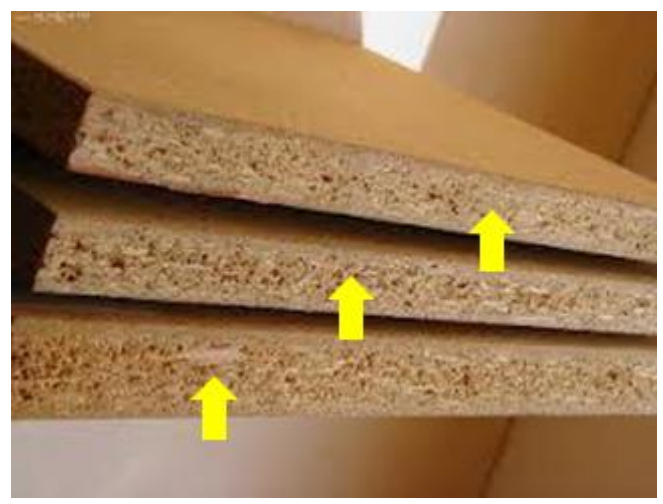

Gambar 1. Produk papan partikel dari limbah serbuk gergaji

Selain limbah serbuk gergaji kayu, limbah cangkang telur ayam yang dihasilkan oleh pengusaha roti juga perlu mendapat perhatian dalam hal pembuangan dan pemanfaatan limbahnya. Cangkang telur ayam mengandung kalsium karbida $\left(\mathrm{CaCO}_{3}\right)$ yang sangat tinggi sehingga cangkang telur merupakan sumber bio- $\mathrm{CaCO}_{3}$ (Qolis, 2020; Qhazi 2017) yang berpotensi untuk berbagai aplikasi tentunya. Pengolahan limbah cangkang telur masih memiliki kesempatan cukup luas karena sejauh ini limbah cangkang telur diolah menjadi produk kerajinan (Maida, 2019) dan dibuat tepung untuk meningkatkan tingkat kerenyahan kerupuk (Qolis, 2020).

Pembuatan bahan komposit menggunakan bahan pengisi serbuk gergaji dengan bahan pengikat epoxy resin (serbuk gergaji/epoxy) dan serbuk cangkang telur/epoxy telah dilaporkan. serbuk gergaji kayu merupakan salah satu sumber selulosa dengan kadar dalam rentang 40-50\% tergantung jenis kayunya dan berfase semikristalin (Qhazi, 2017; Mian et al., 2018). Cangkang telur mengandung $\mathrm{CaCO}_{3}$ dengan kadar yang relatif tinggi (> 90\%) memiliki kompatibilitas dengan epoxy resin (Owuamaman, 2020; Puspitasari et al., 2020) sehingga dapat meningkatkan kekuatan mekanis paduan $\mathrm{CaCO}_{3}$ dan epoxy resin pada komposit $\mathrm{CaCO}_{3} /$ epoxy.

Dari sumber informasi di jurnal nasional dan internasional, pembuatan bahan komposit yang dilakukan kebanyakan hanya menggunakan bahan pengisi/penguat limbah cangkang telur atau serbuk gergaji kayu. Namun, pembuatan bahan komposit hibrid dengan perpaduan serbuk gergaji dan serbuk cangkang telur sebagai bahan pengisi dan bahan 
pengikat epoxy resin relatif masih langka bahkan belum ditemukan informasinya.

Oleh karena itu, melalui Program Pengembangan Desa Mitra (PPDM) ini limbah gergaji halus akan diolah menjadi produk inovatif meuble hibrid untuk aplikasi meja makan pasien di rumah sakit (RS) atau klinik. Meja/ meuble hibrid dibuat dari papan komposit menggunakan limbah cangkang telur ayam yang ditambahkan sebagai bahan aditif ke dalam campuran serbuk gergaji dan epoxy resin. Pemanfaatan kedua limbah tersebut, diharapkan dapat membantu memberikan solusi pengolahan limbah tersebut. Pada papan komposit juga dilakukan uji bending (tekuk) untuk membandingkan salah satu sifat mekanis papan komposit yang ditambah serbuk cangkang telur dan tidak menggunakan serbuk cangkang telur, serta kerapatannya dibandingkan dengan papan partikel (Gambar 1). Produk meja dibuat dengan gerakan yang fleksibel sehingga memudahkan pasien dan sangat bermanfaat untuk pasien usia lanjut. Meja dapat digerakan naik turun dan 4 buah roda dipasang pada kaki meja yang membuat meja dapat diputar $360^{\circ}$.

\section{METODE PELAKSANAAN}

Bahan yang digunakan untuk fabrikasi adalah limbah serbuk gergaji kayu halus yang diperoleh dari pengusaha Syifa Meubel, Kecamatan Mungkid, Kabupaten Magelang. Untuk limbah cangkang telur diperoleh dari pengusaha roti yang ada di Yogyakarta, yaitu Joyo Roti. Sedangkan epoxy resin terdiri dari resin (Bisphenol Aepiclorohydrin) dan hardener (Polyaminoamide) dari EposchÖn. Gambar 2 menunjukkan diagram alir proses fabrikasi papan komposit hibrid yang akan dibuat meja pasien RS/Klinik.

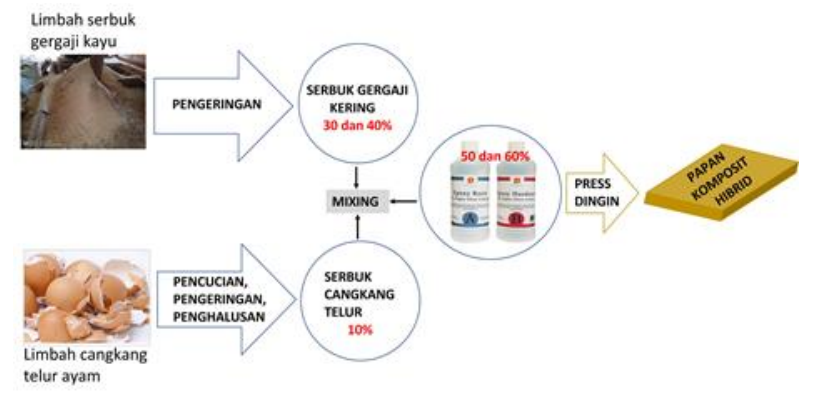

Gambar 2. Diagram alir proses fabrikasi komposit hibrid serbuk gergaji/serbuk cangkang telur/epoxy

Metode fabrikasi papan komposit hibrid diawali dengan persiapan bahan-bahan komponen komposit dan pembuatan cetakan papan komposit yang dibuat dari logam Al (aluminium) (Gambar 3). Serbuk gergaji kayu perlu dikeringkan terlebih dahulu. Cangkang telur harus dicuci, dikeringkan dan dihancurkan/dihaluskan dengan blender menjadi ukuran yang kecil dalam skala milimeter. Resin dan hardener dibuat dengan perbandingan 1:1. Selanjutnya papan komposit dibuat dengan perbandingan 30 - 40\% bahan pengisi (serbuk gergaji kayu dan cangkang telur) dan $50-60 \%$ epoxy resin. Selain itu, cetakan untuk pembuatan komposit dengan ukuran sesuai dengan ukuran meja yang dibuat ( $64 \mathrm{~cm} \times 36 \mathrm{~cm} \times 3 \mathrm{~cm}$ ). Penentuan komposisi bahan komposit ini mengacu pada pengalaman penelitian komposit serat alam berbasis epoxy [Sosiati et al., 2020] dan penelitian sebelumnya tentang pembuatan komposit serbuk gergaji/epoxy [Mian et al., 2018; Nugroho \& Asroni, 2016] dan cangkang telur/epoxy [Abdel-Rahim et al., 2019; Hameed \& Jassim, 2019].

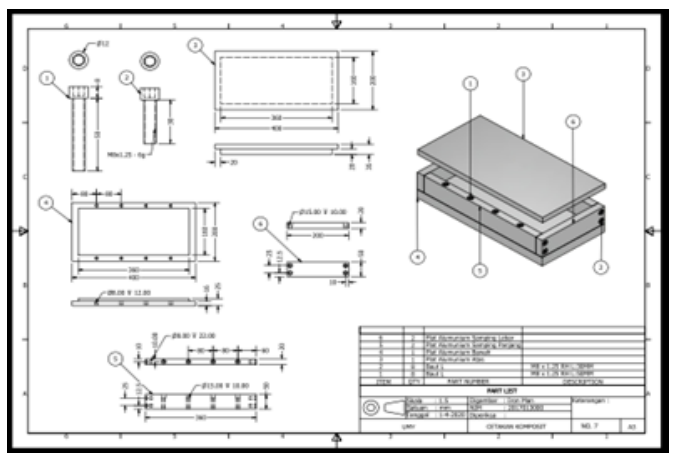

(a)

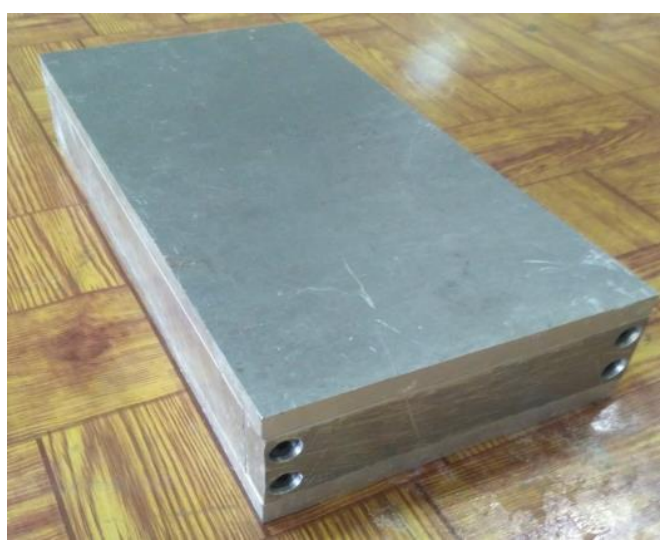

(b)

Gambar 3. Cetakan papan komposit untuk meja hibrid. (a) Desain gambar teknik cetakan, dan (b) hasil pembuatan cetakan dari logam Al

Gambar 4 menunjukkan kegiatan proses fabrikasi komposit serbuk gergaji/epoxy dan serbuk gergaji/serbuk cangkang telur/epoxy. Pertama serbuk gergaji, serbuk cangkang telur dan epoxy disiapkan dengan komposisi persen berat. Sebelum komponen-komponen tersebut disusun kedalam 
cetakan, terlebih dahulu serbuk cangkang telur dan epoxy dicampur menggunakan mesin pengaduk selama kurang lebih 5 menit agar sebaran serbuk cangkang telur di dalam matrik epoxy merata. Setelah komponen komposit disusun dalam cetakan kemudian di press pada suhu $100^{\circ} \mathrm{C}$ selama 30 menit.

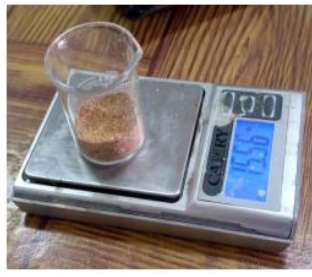

(a)

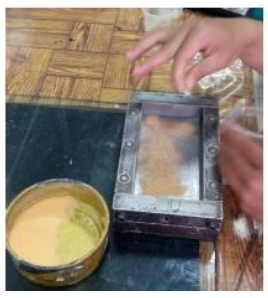

(d)

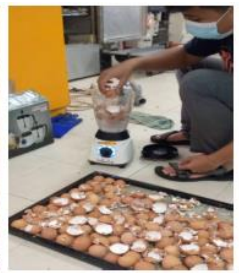

(b)

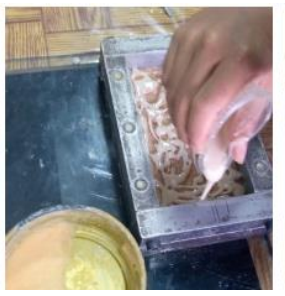

(e)

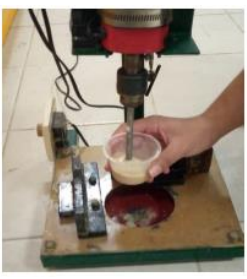

(c)

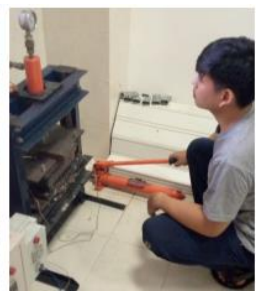

(f)
Gambar 4. Proses fabrikasi papan komposit untuk sampel uji. (a) Penimbangan serbuk gergaji, (b) pembuatan serbuk cangkang telur, (c) pencampuran/blending serbuk cangkang telur dan epoxy, (d) dan (e) penyusunan komponen komposit dalam cetakan, dan (f) pengepresan papan komposit

Selain itu, uji bending dilakukan pada sampel komposit serbuk gergaji/epoxy dan komposit hibrid serbuk gergaji/serbuk cangkang telur/epoxy untuk mengetahui sifat lenturnya. Sampel komposit untuk uji bending dengan ukuran $127 \mathrm{~mm} \times 12.7 \mathrm{~mm} \times 3.2$ $\mathrm{mm}$ dibuat mengikuti ASTM D790. Selanjutnya hasil sifat bending (lentur) komposit dibandingkan dan kerapatannya dibandingkan dengan papan partikel yang diproduksi di pasaran (komersial).

Dalam hal ini, fabrikasi papan komposit untuk meja hibrid dilakukan dengan pengepresan pada suhu kamar. Hal ini dilakukan untuk menghindari distribusi suhu yang tidak homogen dalam papan komposit mengingat volumenya cukup besar.

\section{PEMBAHASAN \\ Sampel Papan Komposit}

Gambar 5 menunjukkan produk sampel papan komposit yang siap diuji bending dengan ukuran sesuai ASTM D790. Hasil uji bending sampel komposit ditunjukkan pada Tabel 1. Dari hasil tersebut dapat dilihat bahwa penambahan $10 \%$ serbuk cangkang telur pada komposit serbuk gergaji/epoxy tidak menunjukkan penurunan kuat bending, dan kenaikkan modulus dan regangan bending yang signifikan. Penurunan maupun kenaikan hanya sekitar $4 \%$. Akan tetapi, kerapatan papan komposit serbuk gergaji/epoxy dan komposit hibrid serbuk gergaji/serbuk cangkang telur/epoxy terlihat jauh lebih rapat dibandingkan papan partikel (Gambar 6).

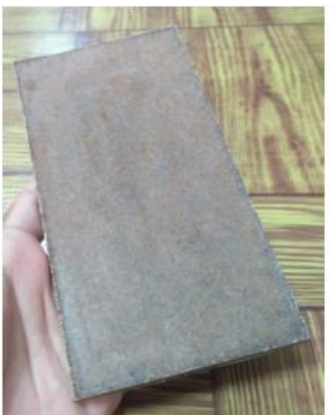

(a)

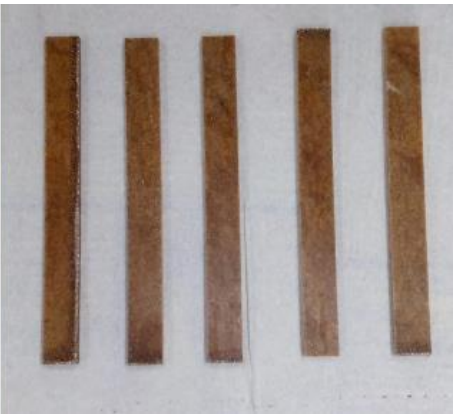

(b)
Gambar 5. Produk sampel papan komposit (a) dan sampel siap uji bending (b)

Tabel 1. Sifat bending sampel komposit

\begin{tabular}{cccc}
\hline $\begin{array}{c}\text { Sampel } \\
\text { komposit }\end{array}$ & $\begin{array}{c}\text { Kuat } \\
\text { bending } \\
\text { (MPa) }\end{array}$ & $\begin{array}{c}\text { Modulus } \\
\text { bending } \\
\text { (GPa) }\end{array}$ & $\begin{array}{c}\text { Regangan } \\
\text { bending } \\
\text { (\%) }\end{array}$ \\
\hline $\begin{array}{c}\text { Serbuk } \\
\text { kayu/epoxy }\end{array}$ & 31,86 & 1,32 & 5,53 \\
$\begin{array}{c}\text { (40:60) wt.\% } \\
\text { Serbuk }\end{array}$ & & & \\
$\begin{array}{c}\text { gergaji/serbuk } \\
\text { cangkang } \\
\text { telur/epoxy }\end{array}$ & 30,47 & 1,37 & 4,73 \\
(30:10:60) wt.\% & & & \\
\hline
\end{tabular}

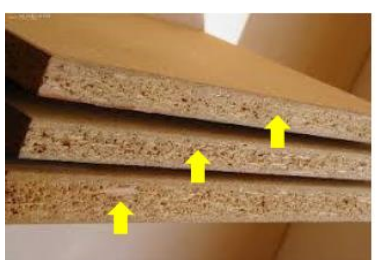

(a)

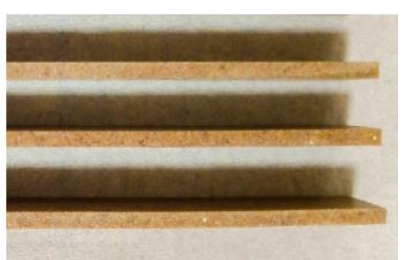

(b)

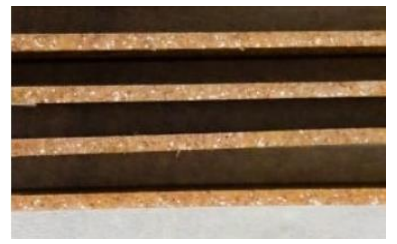

(c)

Gambar 6. Perbandingan kerapatan papan partikel komersial (a) dan produk komposit serbuk gergaji/epoxy (b) dan serbuk gergaji/serbuk cangkang telur/epoxy (c) diamati dari sisi penampang lintang. 


\section{Papan Komposit untuk Meja Hibrid}

Untuk pembuatan meja hibrid, papan komposit yang dicetak adalah komposit serbuk gergaji/serbuk cangkang telur/epoxy dengan perbandingan (30:10:60) dan (40:10:50) dalam \% berat (Gambar 7). Rasio komponen bahan komposit ini ditentukan berdasarkan hasil uji kuat lentur komposit yang dilakukan sebelum fabrikasi bahan untuk meja hibrid.

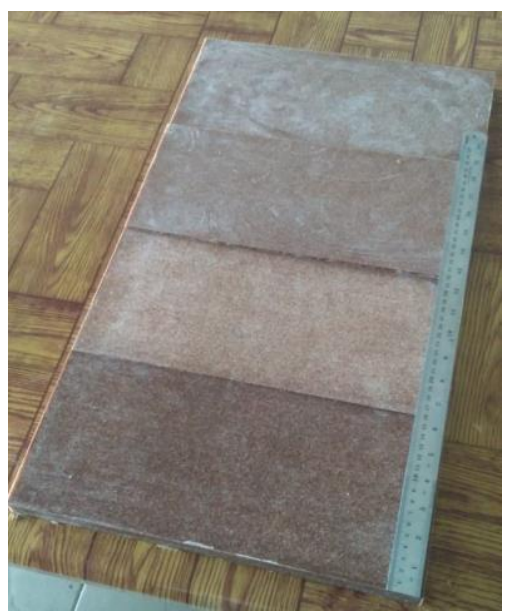

Gambar 7. Papan komposit siap dibuat meja hibrid

Dalam hal ini, untuk membuat meja hibrid yang ekonomis dapat dilakukan dengan menurunkan fraksi berat epoxy resin. Jika porsi epoxy diturunkan hingga 40 atau 30\%, maka meja hibrid akan lebih ekonomis. Namun, jika porsi epoxy resin sebagai bahan pengikat terlalu rendah maka epoxy resin tidak cukup untuk mengikat atau membasahi seluruh bahan pengisi (serbuk gergaji dan cangkang telur). Oleh karena itu, pada pembuatan meja hibrid ini digunakan dua macam nilai fraksi berat epoxy resin yaitu $60 \%$ dan $50 \%$ sehingga dapat menghasilkan meja hibrid yang berkualitas.

\section{Produk meja hibrid}

Meja hibrid yang dihasilkan berjumlah dua meja yang dibuat menggunakan papan komposit dengan fraksi berat epoxy resin $60 \%$ dan $50 \%$, dan $10 \%$ serbuk cangkang telur untuk masing-masing meja dan sisanya adalah serbuk gergaji (Gambar 8). Namun, sifat bahan yang digunakan pada kedua produk meja hibrid ini tidak memiliki perbedaan yang signifikan (Tabel 1) sehingga meja hibrid dapat diproduksi dengan kedua komposisi tersebut. Dari sisi kepadatan dan durability material untuk produk meja ini akan lebih unggul dibandingkan dengan produk meja di pasaran yg dibuat dari papan partikel.

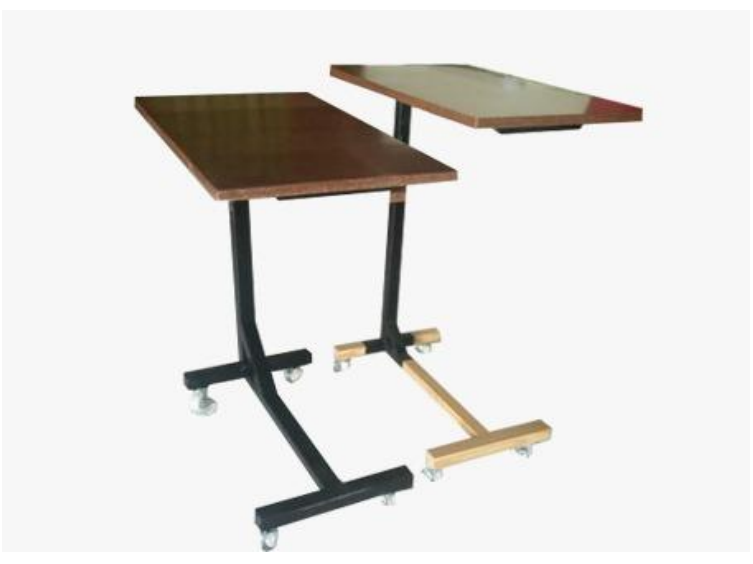

Gambar 8. Meja hibrid untuk pasien rumah sakit

Meja ini dibuat oleh Mitra-1 "Syifa Meubel" (Gambar 9) menjadi meja yang fleksibel, yaitu dapat diatur tinggi rendahnya dan pada kaki meja dipasang roda sehingga memudahkan pasien untuk menggeser meja setelah selesai digunakan. Oleh karena itu, produk meja hibrid ini dihibahkan ke "Klinik Pratama BKIA Aisyiah" sebagai Mitra-2 yang berlokasi di desa yang sama dengan Mitra-1. Hibah meja hibrid ini diharapkan dapat bermanfaat untuk pasien yang sedang dirawat di klinik tersebut. Selain fungsi meja tersebut fleksibel, meja tersebut juga tidak rapuh jika ada air minum yang tumpah diatas meja tersebut. Hal ini sangat memungkinkan apabila pasien berusia lanjut yang pada umumnya mengalami tremor. Gambar 10 memperlihatkan profil Mitra-2 dan serah terima produk meja hibrid, sekaligus sosialisasi cara efektif penggunaan meja hibrid kepada dokter dan nakes di klinik tersebut.

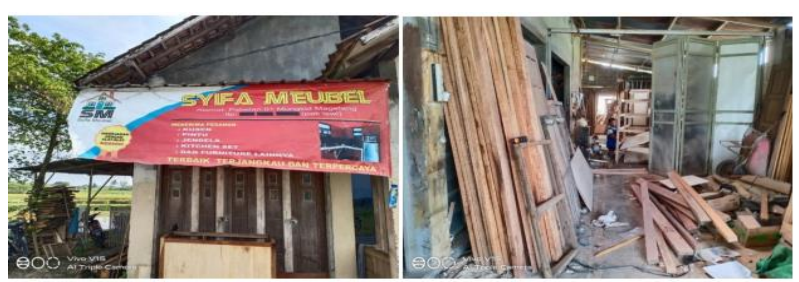

Gambar 9. Profil Syifa Meubel sebagai Mitra-1

Setelah kegiatan pengabdian selesai dilaksanakan, kami mengadakan evaluasi kepada mitra penerima hibah untuk melihat manfaat dari meja hibrid untuk pasien di klinik tersebut. Dari hasil evaluasi, kami mendapatkan respon yang positif. Hal ini dikarenakan meja tersebut sangat fleksibel dan praktis untuk digunakan, terlebih untuk pasien usia lanjut. Meja tersebut dapat diposisikan secara fleksibel tergantung kebutuhan pasien, sehingga membuat pasien merasa lebih nyaman saat 
menggunakan meja tersebut dibandingkan dengan meja pasien yang lain.

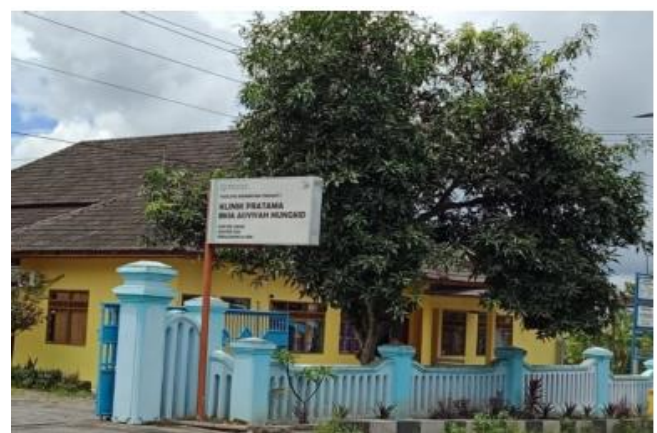

(a)

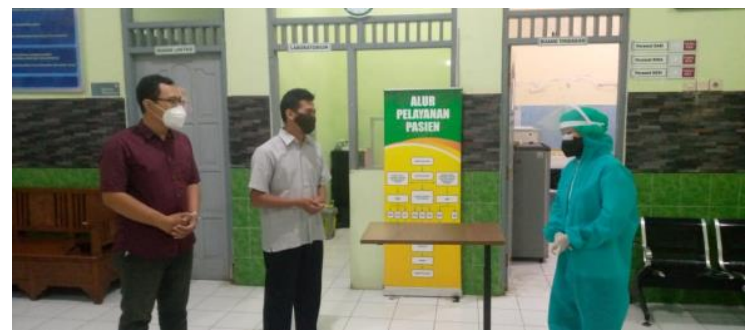

(b)

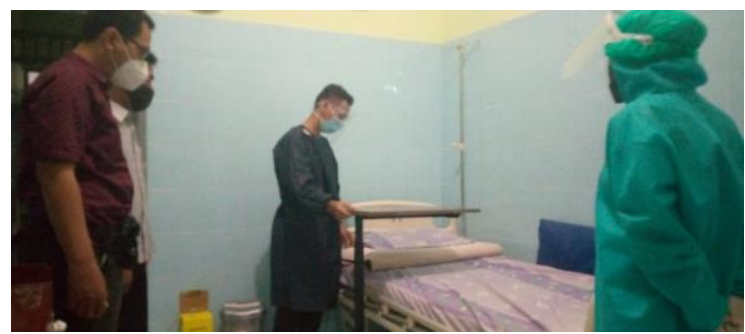

(c)

Gambar 10. (a) Profil Klinik Pratama BKIA Aisyiah sebagai Mitra-2, dan (b) dan (c) proses serah terima produk meja hibrid untuk pasien klinik dan sosialisasi cara penggunaannya

\section{KESIMPULAN}

Kegiatan PPDM ini telah menghasilkan papan komposit serbuk gergaji/epoxy dan komposit hibrid serbuk gergaji/serbuk cangkang telur/epoxy yang menunjukkan kerapatan lebih tinggi dibandingkan papan partikel yang ada di pasaran. Hal ini membuat durability (waktu pakai) meja menjadi lebih lama dan tidak rentan terhadap air. Selain dapat memberikan solusi pemanfaatan limbah serbuk gergaji dan cangkang telur, hasil kegiatan ini juga memberikan nilai positif yang berpotensi untuk dikembangkan menjadi produk meja hibrid yang berkualitas untuk aplikasi meja makan pasien rumah sakit yang fleksibel. Selain itu, teknologi fabrikasi papan komposit dari kegiatan ini menjadi basis kegiatan berikutnya, yaitu meningkatkan nilai ekonomis limbah serat alam sebagai bahan penguat produk komposit untuk jenis aplikasi lainnya. Kegiatan pengabdian masyarakat berikutnya dapat dilakukan pemanfaatan limbah serat alam (bambu) yang diolah menjadi perangkat medis.

\section{UCAPAN TERIMA KASIH}

Penulis mengucapkan terima kasih kepada Lembaga Pengabdian Masyarakat (LPM), UMY atas dukungan dana (SK No. PEN-LP3M/II/ 2021) hingga kegiatan pengabdian masyarakat program PPDM berhasil dilaksanakan dengan baik. Selain itu, penulis juga menyampaikan apresiasi kepada mitra yang mendukung kegiatan pengabdian masyarakat ini, yaitu Syifa Meubel dan Klinik Pratama BKIA Aisyiah, Kecamatan Mungkid, Kabupaten Magelang.

\section{DAFTAR PUSTAKA}

Abdel-Rahim, R. H. \& Mohammed, R. A. (2019). Experimental investigation of some properties of epoxy reinforced by egg shell particles. International Journal of Mechanical Engineering and Technology, 10(1), 152-163. http://www.iaeme.com/MasterAdmin/Journal_uplo ads/IJMET/VOLUME_10_ISSUE_1/IJMET_10_01_015.pdf

Cahyandari, D. (2007). Pemanfaatan limbah kayu sebagai bahan dasar pembuatan papan partikel. TRAKSI, 5(1), 26-34. https://jurnal.unimus.ac.id/index.php/jtm/article/vie w/605

Hameed, H. K., \& Jassim, W. H. (2019, December). Improvement of some mechanical properties of epoxy using uncarbonized and carbonized eggshell powder. In AIP Conference Proceedings (Vol. 2190, No. 1, p. 020026). AIP Publishing LLC. https://doi.org/10.1063/1.5138512

Kurniawan, A., (2020). Jenis Kayu, Informasi. https://www.merdeka.com/jabar/8-jenis-kayu-yangada-di-indonesia-ketahui-manfaat-dankelebihannya-kln.html

Maida, A. N., \& Sumiyati, S. (2019). Pemanfaatan Cangkang dan Rak Telur Sebagai Hiasan Dinding. In SemanTECH (Seminar Nasional Teknologi, Sains dan Humaniora) (Vol. 1, No. 1, pp. 309-315). http://jurnal.poligon.ac.id/index.php/semantech/arti cle/view/496

Mian, I.U., Alam, S., Li, X., Zeong, M., Rehman, N., Ma, F., Khan, A. \& Mehreen, (2018). Isolation of Cellulose from Sawdust of Cedrus Deodara: Effect of Preparation Condition on their Morphological Behavior, The International Journal of Science and Technoledge, 5 (2), $140-146$ http://internationaljournalcorner.com/index.php/thei jst/article/view/123718

Nugroho, E., \& Asroni, A. (2017). Pengaruh Komposisi Resin Terhadap Kekuatan Mekanik Papan Partikel Yang Diperkuat Serbuk Kayu Akasia. Turbo: Jurnal Program Studi Teknik Mesin, 5(2), 99-107. https://doi.org/10.24127/trb.v5i2.242 
Owuamanam, S., \& Cree, D. (2020). Progress of bio-calcium carbonate waste eggshell and seashell fillers in polymer composites: a review. Journal of Composites Science, $4(2)$,

70-92. https://doi.org/10.3390/jcs4020070

Puspitasari, P., Utomo, D.M., Naufal Zhorifah, H.K., Permanasari, A.A., Gayatri, R.W., (2020). Physicochemical Determination of Calcium Carbonate $\left(\mathrm{CaCO}_{3}\right)$ from Chicken Eggshell, Key Engineering Materials, Vol. 840, pp. 478-483. https://doi.org/10.4028/www.scientific.net/KEM.840.4 78

Qhazi, I. F. (2017). Study the effect of the particle size on mechanical properties of particulate natural composite materials. al-qadisiyah journal for engineering sciences, 10(2), 120-132. https://qu.edu.iq/journaleng/index.php/JQES/article $/$ view/194

Qolis, N., Handayani, C. B., \& Asmoro, N. W. (2020). Fortifikasi kalsium pada kerupuk dengan subtitusi tepung cangkang telur ayam ras. Jurnal Teknologi Pangan, 14(1),

30-39. https://doi.org/10.33005/jtp.v14i1.2181

Pasaribu, G., \& Sisilia, L. (2021). Peningkatan mutu kayu jati (Tectona grandis) hasil penjarangan asal Kabupaten Cianjur. jurnal Tengkawang: Jurnal IImu Kehutanan. 2
(1), 27-37. https://jurnal.untan.ac.id/index.php/tengkawang/ar ticle/view/1639

Purba, R. E. S., Irwan, I., \& Nurmaidah, N. (2017). Pemanfaatan Limbah Serbuk Gergaji Kayu Sebagai Subtitusi Campuran Bata Ringan Kedap Suara. Journal of Civil Engineering Building and Transportation, 1 (2),

87-95.

https://doi.org/10.31289/jcebt.v1i2.1679

Sosiati, H., Utomo, C. T., Setiono, I., \& Budiyantoro, C. (2020). Effect of $\mathrm{CaCO} 3$ particles size and content on impact strength of kenaf/CaCO3/epoxy resin hybrid composites. Indones. J. Appl. Phys, 10, 24-31. https://doi.org/10.13057/ijap.v10i01.37748

Supriyanto, A., Sari, N. M., \& Radam, R. R. (2020). Pembuatan papan partikel dari serbuk gergajian kayu akasia mangium (acacia mangium) dan kayu sungkai (peronema canescens) menggunakan perekat resin polyester. Jurnal Sylva Scienteae, 3(5), 805-817. https://ppjp.ulm.ac.id/journals/index.php/jss/article/ view/2529

Suwaedi, O. (2018). Pemanfatan Limbah Serbuk Gergaji Sebagai Bahan Dasar Pembuatan Briket. Biosel: Biology Science and Education, 7(2), 204-212. https://doi.org/10.33477/bs.v7i2.656 